\title{
Comparative studies on the hypercholesterolaemia induced by excess dietary tyrosine or polychlorinated biphenyls in rats*
}

\author{
By SATOSHI NAGAOKA, MITSUHIRO KATO, YORITAKA AOYAMA \\ AND AKIRA YOSHIDA \\ Laboratory of Nutritional Biochemistry, Department of Agricultural Chemistry, \\ Nagoya University, Nagoya 464, Japan
}

(Received 9 October 1985 - Accepted 21 May 1986)

\begin{abstract}
1. The effects of dietary polychlorinated biphenyls (PCB) and excess tyrosine on serum and liver lipids, urinary ascorbic acid and catecholamines were compared in male Wistar rats.

2. Serum levels of cholesterol, urinary ascorbic acid, norepinephrine, epinephrine, dopamine and histamine were significantly increased in rats given either $\mathrm{PCB}$ or excess tyrosine.

3. The hypercholesterolaemia induced by PCB or excess tyrosine was blocked by the adrenergic $\alpha$-blocker, phenoxybenzamine.

4. The present results suggest causal interrelations between the hypercholesterolaemia induced by dietary PCB or excess tyrosine and the secretion of catecholamines.
\end{abstract}

The metabolism of cholesterol is subject to complex control and is altered by a number of environmental, hormonal and dietary factors. Dietary hypercholesterolaemia in animal experiments is produced mainly by feeding a high-cholesterol diet (Harry et al. 1973). However, we have previously reported that several kinds of xenobiotics, such as polychlorinated biphenyls (PCB), produce hypercholesterolaemia in rats without dietary addition of cholesterol (Kato \& Yoshida, 1981). In these cases, the incorporation of ${ }^{3} \mathrm{H}_{2} \mathrm{O}$ into liver cholesterol was stimulated together with an increase in the activity of liver hydroxymethylglutaryl coenzyme A reductase (NADPH) (EC 1.1.1.34; HMG-CoA reductase), suggesting stimulation of cholesterol synthesis (Kato \& Yoshida, 1980). On the other hand, our previous report revealed that the amino acid tyrosine, which is a precursor of catecholamines, also produced hypercholesterolaemia in rats (Nagaoka et al. 1985).

The feeding of xenobiotics or excess tyrosine per se might stress animals, thereby stimulating the secretion of hormones such as catecholamines and corticosteroids which might stimulate cholesterol synthesis. Many investigators suggested that catecholamines may be of importance in regulating the rate of hepatic cholesterol synthesis and the activity of HMG-CoA reductase, a rate-limiting enzyme in cholesterol synthesis (Edwards, 1975; Rajan \& Ramasarma, 1977). We speculated that there may be some common mechanisms involved in hypercholesterolaemia. In the present study, therefore, we investigated the interrelations between the hypercholesterolaemia induced by dietary PCB or excess tyrosine and some hormones such as catecholamines, histamine and corticosteroids which might be involved in the mechanism of this type of hypercholesterolaemia.

\section{MATERIALS AND METHODS}

Animals and diets

Male Wistar rats, weighing about $90 \mathrm{~g}$, were distributed into groups of six rats. They were fed on a commercial diet (CE-2; Japan CLEA Co. Ltd, Tokyo) for $3 \mathrm{~d}$ to allow them to

\footnotetext{
* Supported in part by a grant from the Nissan Science Foundation and Elizabeth Arnold Fuji Foundation, Japan. 
Table 1. Composition of the diets $(\mathrm{g} / \mathrm{kg})$

\begin{tabular}{lrrrrr}
\hline Diet... & Control & \multicolumn{2}{c}{ Tyrosine } & \multirow{2}{*}{ PCB } \\
\cline { 3 - 5 } Ingredients & & Expt 1 & Expt 2 \\
\hline Casein* & & \\
L-Tyrosine & 200 & 200 & 200 & 200 \\
PCB & - & 120 & 100 & - \\
Mineral mixture $\dagger$ & 50 & 50 & 50 & $0 \cdot 3$ \\
Vitamin mixture $\dagger$ & 5 & 5 & 5 & 5 \\
Choline chloride & 2 & 2 & 2 & 2 \\
Maize oil & 20 & 20 & 20 & 20 \\
Sucrose & 482 & 201 & 208 & $240 \cdot 9$ \\
Starch & 402 & 415 & $481 \cdot 8$ \\
Retinyl palmitate (mg) & 15 & 4 & 4 & 4 \\
Ergocalciferol $(\mu \mathrm{g})$ & 15 & 15 & 15 \\
DL- $\alpha$-Tocopheryl acetate (mg) & 100 & 100 & 100 & 100 \\
\hline
\end{tabular}

PCB, polychlorinated biphenyls.

* The tyrosine content of the casein is $59 \mathrm{~g} / \mathrm{kg}$ casein (Orr \& Watt, 1957).

$\dagger$ Composition as described in Harper (1959).

adjust to their new environment, and then offered a diet adequate in casein $(200 \mathrm{~g} / \mathrm{kg})$ for $2 \mathrm{~d}$ before feeding the test diets shown in Table 1 . Room temperature was kept at $22 \pm 2^{\circ}$ with a $12 \mathrm{~h}$ light $-12 \mathrm{~h}$ dark cycle (lights on 08.00-20.00 hours). All rats were individually housed and provided with food and water ad lib. L-Tyrosine (Ajinomoto Co. Ltd) and PCB (Aroclor 1248; Mitsubishi Monsant Co. Ltd, Tokyo) were added to the diet as shown in Table 1. Changes in the dietary level of tyrosine or PCB were compensated by adjusting the amount of carbohydrate, composed of one part sucrose and two parts gelatinized maize starch. Fat-free diets were prepared by replacing maize oil with carbohydrate.

\section{Experimental procedure}

Expt 1. Rats were fed ad lib. on diets supplemented with either PCB $(0.3 \mathrm{~g} / \mathrm{kg})$ or tyrosine $(120 \mathrm{~g} / \mathrm{kg})$ for $28 \mathrm{~d}$. On days $9-10$, urine was collected into $20 \mathrm{ml} 0 \cdot 1 \mathrm{M}$-hydrochloric acid and used for the determination of ascorbic acid, histamine and catecholamines. For $24 \mathrm{~h}$ before killing (19.00 hours), the animals were given fat-free diets. At the end of the experimental period, rats were anaesthetized with dry ice and killed at 19.00 hours within a 30 min period.

Expt 2. (1) $\alpha$-Blocker treatment. Groups of animals received orally, between 10.00 and 11.00 hours, $30 \mathrm{mg}$ phenoxybenzamine hydrochloride (Tokyo Kasei Kogyo Co.; an $\alpha$-adrenergic blocker) $/ \mathrm{kg}$ per $\mathrm{d}$ dissolved in an ethanol $(15 \mathrm{~g} / \mathrm{l})$ solution containing saline ( $9 \mathrm{~g}$ sodium chloride/l) for $7 \mathrm{~d}$, followed by $40 \mathrm{mg}$ phenoxybenzamine hydrochloride $/ \mathrm{kg}$ per $\mathrm{d}$ for $7 \mathrm{~d}$. The total period of administration of the $\alpha$-blocker was $14 \mathrm{~d}$. Test diets were supplemented with L-tyrosine $(100 \mathrm{~g} / \mathrm{kg})$ or PCB $(0.3 \mathrm{~g} / \mathrm{kg})$. Because of the depression of food intake by $\alpha$-blocker treatment, pair-fed groups were also included. The groups, except for $\alpha$-blocker-treated groups, received the ethanol $(15 \mathrm{~g} / \mathrm{l})$ solution containing saline. The drug was administered by oesophageal intubation at $2.5 \mathrm{ml} / \mathrm{kg}$ body-weight. The dosage of phenoxybenzamine was based on previous pharmacological studies (Rajan \& Ramasarma, 1977; Kunihara \& Oshima, 1983) and preliminary experiments. On the last day of the experimental period, rats were killed, as described previously, between 13.00 and 14.00 hours, and serum cholesterol was determined. 
Expt 2. (2) $\beta$-Blocker treatment. Rats were fed ad lib. on diets supplemented with either PCB $(0.3 \mathrm{~g} / \mathrm{kg})$ or tyrosine $(100 \mathrm{~g} / \mathrm{kg})$ for $14 \mathrm{~d}$. The animals received orally, between 10.00 and 11.00 hours, $35 \mathrm{mg}$ DL-propranolol hydrochloride (Sigma Chemical Co., Poole, Dorset; a $\beta$-adrenergic blocker) $/ \mathrm{kg}$ per $\mathrm{d}$ for $14 \mathrm{~d}$. The groups, except $\beta$-blocker-treated groups, received saline. The drug was administered through oesophageal intubation at $2.5 \mathrm{ml} / \mathrm{kg}$ body-weight. The dosage of propranolol was based on previous pharmacological studies (Rajan \& Ramasarma, 1977; Heimburger et al. 1983; Kunihara \& Oshima, 1983) and preliminary experiments. On the last day of the experimental period, rats were killed, as described previously, between 13.00 and 14.00 hours. Serum cholesterol was determined.

\section{Measurements}

Serum and liver cholesterol levels were measured according to the method of Pearson $e t$ al. (1953). High-density lipoprotein (HDL)-cholesterol was separated by the heparinmanganese method described by Ishikawa et al. (1978). Serum triglyceride value was estimated by the method of Wahlefeld (1974). Serum phospholipid was assayed with a commercially-available kit (Phospholipid-Test; Wako Pure Chemical Industries Ltd) by a method described by Zilversmit \& Davis (1950). Liver lipids were extracted by the method of Folch et al. (1957). Liver total lipids were determined gravimetrically. Total lipidphosphorus was determined by the method of Bartlett (1959), and the values were multiplied by 25 to obtain the phospholipid content of liver. Liver triglyceride value was calculated from liver total lipids minus liver cholesterol and phospholipid. Ascorbic acid was measured by the 2,4-dinitrophenylhydrazine method (Ohara, 1973). Serum corticosterone was analysed fluorometrically using a spectrofluorometer (Jasco FP-550A) according to the method of Gibbs (1970). Urinary histamine was measured according to the method described by Anton \& Sayre (1969). Urinary catecholamines were measured according to the method described by Kissinger et al. (1977) using high-performance liquid chromatography (Yanaco L-3200 V).

\section{Statistics}

The statistical significance of differences between values was analysed by Duncan's multiple-range test (Duncan, 1955).

\section{RESULTS}

\section{Expt 1}

The effects of excess dietary tyrosine and PCB on serum and liver lipids, serum corticosterone, urinary ascorbic acid, histamine, norepinephrine, epinephrine and dopamine in rats were investigated (Table 2). Serum and liver cholesterol levels increased significantly in the group given the PCB $(0.3 \mathrm{~g} / \mathrm{kg})$ diet at day 28 . The serum cholesterol level was significantly increased in rats given the casein $(200 \mathrm{~g} / \mathrm{kg})$ diet supplemented with tyrosine $(120 \mathrm{~g} / \mathrm{kg})$ at day 28 . Food intake and body-weight gain of rats given either the tyrosine $(120 \mathrm{~g} / \mathrm{kg})-$ or the PCB $(0 \cdot 3 \mathrm{~g} / \mathrm{kg})$-supplemented diet were almost the same as the corresponding values for the control group, although hepatomegaly was observed. Dietary PCB increased the level of triglyceride, phospholipid and cholesterol in the liver. Liver total lipids and triglyceride were significantly depressed by the diet with excess tyrosine, but liver phospholipid was not significantly altered, when expressed as $\mathrm{mg} / \mathrm{g}$ tissue. Furthermore, liver levels of total lipids in rats given the tyrosine $(120 \mathrm{~g} / \mathrm{kg})$-supplemented diet were almost the same as those in the control group, when expressed as $\mathrm{mg} / \mathrm{kg}$ body-weight (not shown in Table 2). Serum levels of corticosterone were not significantly altered by excess tyrosine or PCB. Urinary ascorbic acid was significantly increased in groups given either the PCB or excess tyrosine diet, but the increase was much greater in the PCB-fed group. Histamine 
Table 2. Expt 1. Effects of dietary addition of tyrosine or polychlorinated biphenyls $(P C B)$ on serum and liver lipids, urinary ascorbic acid, histamine, norepinephrine, epinephrine and dopamine in rats

(Mean values with their standard errors for six rats per group)

\begin{tabular}{|c|c|c|c|c|c|c|}
\hline \multirow[t]{2}{*}{ Dietary treatment... } & \multicolumn{2}{|c|}{$\begin{array}{c}\text { Control } \\
(200 \mathrm{~g} \text { casein } / \mathrm{kg})\end{array}$} & \multicolumn{2}{|c|}{$\begin{array}{l}\text { Tyrosine } \\
(120 \mathrm{~g} / \mathrm{kg})\end{array}$} & \multicolumn{2}{|c|}{$\begin{array}{c}\text { PCB } \\
(0 \cdot 3 \mathrm{~g} / \mathrm{kg})\end{array}$} \\
\hline & Mean & SE & Mean & SE & Mean & SE \\
\hline Food intake, day $8(\mathrm{~g} / \mathrm{d})$ & $13 \cdot 5^{\mathrm{a}}$ & $0 \cdot 7$ & $13 \cdot 8^{\mathrm{a}}$ & $0 \cdot 6$ & $13 \cdot 7^{\mathrm{a}}$ & 0.7 \\
\hline Body-wt gain $(g / 28 d)$ & $115 \cdot 2^{\mathrm{a}}$ & $5 \cdot 4$ & $113 \cdot 5^{\Omega}$ & $3 \cdot 7$ & $109 \cdot 3^{\mathrm{a}}$ & $6 \cdot 0$ \\
\hline Liver wt ( $\mathrm{g} / \mathrm{kg}$ body-wt) & $43 \cdot 3^{a}$ & $1 \cdot 1$ & $50 \cdot 3^{b}$ & $1 \cdot 1$ & $66 \cdot 7^{\mathrm{e}}$ & $1 \cdot 1$ \\
\hline \multicolumn{7}{|l|}{ Serum: } \\
\hline Cholesterol (mg/1) & $953^{a}$ & 50 & $1224^{\mathrm{b}}$ & 44 & $2028^{c}$ & 55 \\
\hline Triglyceride (mg/l) & $1759^{\mathrm{a}}$ & 218 & $1941^{a}$ & 228 & $1701^{\mathrm{a}}$ & 270 \\
\hline Phospholipid (mg/l) & $2418^{\mathrm{a}}$ & 96 & $2527^{\mathrm{a}}$ & 91 & $3808^{b}$ & 80 \\
\hline Corticosterone $(\mu \mathrm{g} / \mathrm{l})$ & $452^{\mathrm{a}}$ & 45 & $409^{a}$ & 28 & $337^{\mathrm{a}}$ & 43 \\
\hline \multicolumn{7}{|l|}{ Liver (mg/g liver): } \\
\hline Total lipid & $54 \cdot 2^{\mathrm{b}}$ & $0 \cdot 6$ & $48 \cdot 5^{\mathrm{a}}$ & 1.7 & $71 \cdot 8^{\mathrm{c}}$ & 1.6 \\
\hline Cholesterol & $2 \cdot 1^{\mathrm{a}}$ & $0 \cdot 1$ & $2 \cdot 1^{\mathrm{a}}$ & $0 \cdot 1$ & $3 \cdot 4^{b}$ & $0 \cdot 2$ \\
\hline Triglyceride & $23 \cdot 3^{b}$ & 1.0 & $16 \cdot 2^{\mathrm{a}}$ & 1.6 & $29 \cdot 9^{\mathrm{c}}$ & 1.6 \\
\hline Phospholipid & $28 \cdot 8^{\mathrm{a}}$ & $0 \cdot 7$ & $30 \cdot 2^{a}$ & $0 \cdot 8$ & $38 \cdot 5^{\mathrm{b}}$ & 0.5 \\
\hline \multicolumn{7}{|l|}{ Urinary $(/ \mathrm{kg}$ body-wt per $\mathrm{d})$ : } \\
\hline Ascorbic acid (mg) & $1 \cdot 3^{\mathrm{a}}$ & $0 \cdot 1$ & $3 \cdot 8^{b}$ & $0 \cdot 8$ & $100 \cdot 7^{\mathrm{c}}$ & $8 \cdot 5$ \\
\hline Histamine $(\mu \mathrm{g})$ & $119 \cdot 3^{a}$ & $4 \cdot 6$ & $268 \cdot 3^{\mathrm{c}}$ & $21 \cdot 5$ & $173 \cdot 1^{b}$ & $15 \cdot 2$ \\
\hline Norepinephrine $(\mu \mathrm{g})$ & $3 \cdot 40^{\mathrm{a}}$ & 0.69 & $5 \cdot 62^{b}$ & 0.58 & $6.63^{c}$ & 0.67 \\
\hline Epinephrine $(\mu \mathrm{g})$ & $1 \cdot 16^{\mathrm{a}}$ & $0 \cdot 16$ & $1 \cdot 86^{b}$ & $0 \cdot 21$ & $1.96^{\mathrm{b}}$ & $0 \cdot 21$ \\
\hline Dopamine $(\mu \mathrm{g})$ & $12 \cdot 0^{\mathrm{a}}$ & $5 \cdot 3$ & $82 \cdot 7^{\mathrm{e}}$ & $15 \cdot 3$ & $38 \cdot 4^{b}$ & $6 \cdot 2$ \\
\hline
\end{tabular}

a, b, c Mean values within the same horizontal row with unlike superscript letters were significantly different: $P<0.05$.

Table 3. Expt 2. Effects of chronic $\alpha$-blocker treatment on growth, liver weight and adrenal weight in rats given diets supplemented with polychlorinated biphenyls (PCB) or tyrosine

(Mean values with their standard errors for six rats per group)

\begin{tabular}{|c|c|c|c|c|c|c|}
\hline \multirow[b]{2}{*}{ Group } & \multicolumn{2}{|c|}{$\begin{array}{l}\text { Body-wt gain } \\
\quad(g / 14 d)\end{array}$} & \multicolumn{2}{|c|}{$\begin{array}{c}\text { Liver wt } \\
(\mathrm{g} / \mathrm{kg} \text { body-wt })\end{array}$} & \multicolumn{2}{|c|}{$\begin{array}{c}\text { Adrenal wt } \\
(\mathrm{mg} / \mathrm{kg} \text { body-wt })\end{array}$} \\
\hline & Mean & SE & Mean & $\mathrm{SE}$ & Mean & $\mathbf{S E}$ \\
\hline $\begin{array}{l}\text { Pair-fed control }(200 \mathrm{~g} \text { casein } / \mathrm{kg}) \\
\text { Pair-fed PCB }(0 \cdot 3 \mathrm{~g} / \mathrm{kg}) \\
\text { Ad lib. PCB }(0 \cdot 3 \mathrm{~g} / \mathrm{kg})+\alpha \text {-blocker }\end{array}$ & $\begin{array}{l}38 \cdot 2^{\mathrm{a}} \\
38 \cdot 2^{\mathrm{a}} \\
37 \cdot 2^{\mathrm{a}}\end{array}$ & $\begin{array}{l}1 \cdot 5 \\
2 \cdot 0 \\
2 \cdot 1\end{array}$ & $\begin{array}{l}42 \cdot 7^{\mathrm{a}} \\
68 \cdot 2^{\mathrm{b}} \\
68 \cdot 9^{\mathrm{b}}\end{array}$ & $\begin{array}{l}0 \cdot 3 \\
1 \cdot 4 \\
1 \cdot 5\end{array}$ & $\begin{array}{l}193^{\mathrm{a}} \\
190^{\mathrm{a}} \\
189^{\mathrm{a}}\end{array}$ & $\begin{array}{l}5 \cdot 6 \\
6 \cdot 3 \\
8 \cdot 0\end{array}$ \\
\hline $\begin{array}{l}\text { Pair-fed control }(200 \mathrm{~g} \text { casein } / \mathrm{kg}) \\
\text { Pair-fed tyrosine }(100 \mathrm{~g} / \mathrm{kg}) \\
\text { Ad lib. tyrosine }(100 \mathrm{~g} / \mathrm{kg})+\alpha \text {-blocker }\end{array}$ & $\begin{array}{l}41 \cdot 0^{\mathrm{a}} \\
40 \cdot 2^{\mathrm{a}} \\
40 \cdot 8^{\mathrm{a}}\end{array}$ & $\begin{array}{l}3 \cdot 2 \\
3 \cdot 6 \\
4 \cdot 3\end{array}$ & $\begin{array}{l}42 \cdot 6^{\mathrm{a}} \\
51 \cdot 1^{\mathrm{b}} \\
50 \cdot 0^{\mathrm{b}}\end{array}$ & $\begin{array}{l}1 \cdot 1 \\
2 \cdot 7 \\
1 \cdot 1\end{array}$ & $\begin{array}{l}187^{\mathrm{a}} \\
190^{\mathrm{a}} \\
181^{\mathrm{a}}\end{array}$ & $\begin{array}{l}7 \cdot 7 \\
8 \cdot 5 \\
5 \cdot 7\end{array}$ \\
\hline
\end{tabular}

${ }^{a}, \mathrm{~b}$ For each dietary supplement, mean values within the same vertical column with unlike superscript letters were significantly different: $P<0.05$. 


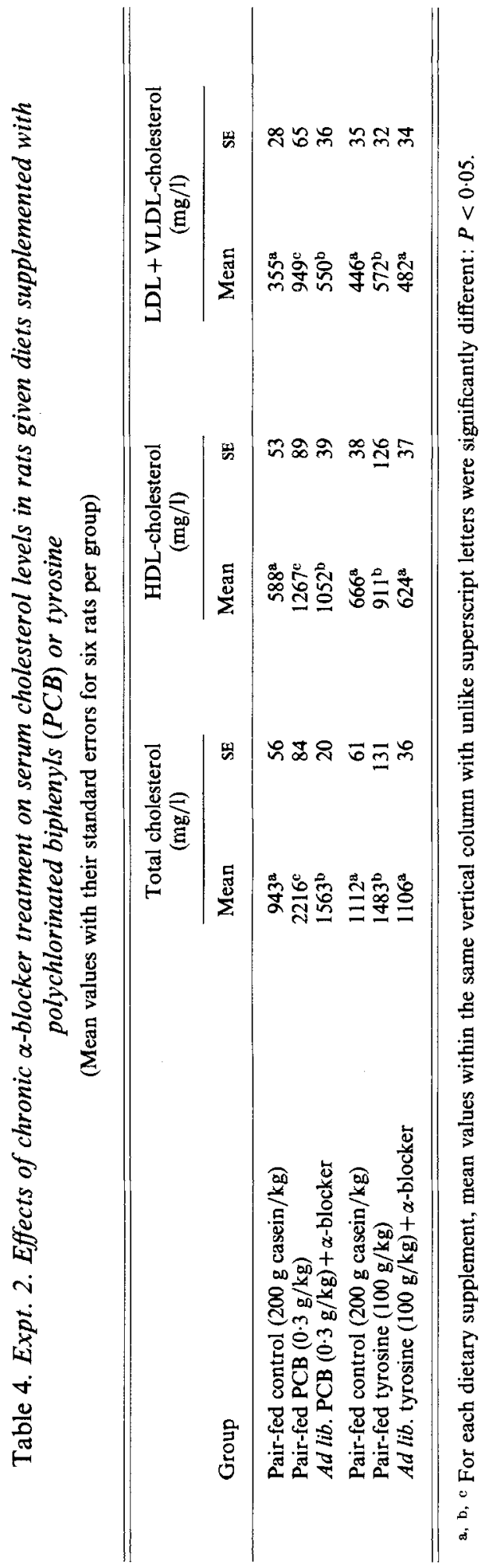


Table 5. Expt 2. Effect of chronic $\beta$-blocker treatment on food intake, body-weight, liver weights and serum cholesterol in rats given diets supplemented with polychlorinated biphenyls $(P C B)$ or tyrosine

(Mean values with their standard errors for six rats per group)

\begin{tabular}{|c|c|c|c|c|c|c|c|c|}
\hline \multirow[b]{2}{*}{ Group } & \multicolumn{2}{|c|}{$\begin{array}{l}\text { Food intake, } \\
\text { day } 12(\mathrm{~g} / \mathrm{d})\end{array}$} & \multicolumn{2}{|c|}{$\begin{array}{l}\text { Body-wt gain } \\
(\mathrm{g} / 14 \mathrm{~d})\end{array}$} & \multicolumn{2}{|c|}{$\begin{array}{c}\text { Liver wt } \\
\text { (g/kg body-wt) }\end{array}$} & \multicolumn{2}{|c|}{$\begin{array}{c}\text { Cholestero } \\
(\mathrm{mg} / \mathrm{l})\end{array}$} \\
\hline & Mean & $\mathrm{SE}$ & Mean & SE & Mean & SE & Mean & $\mathrm{SE}$ \\
\hline Control (200 g casein /kg) & $15 \cdot 4^{\mathrm{a}}$ & $0 \cdot 3$ & $60 \cdot 0^{\mathrm{a}}$ & $1 \cdot 3$ & $44 \cdot 6^{\mathrm{a}}$ & 0.9 & $1013^{\mathrm{a}}$ & 38 \\
\hline $\operatorname{PCB}(0.3 \mathrm{~g} / \mathrm{kg})$ & $14 \cdot 1^{\mathrm{a}}$ & 0.6 & $56 \cdot 7^{\mathrm{a}}$ & $2 \cdot 5$ & $67 \cdot 8^{c}$ & 1.6 & $2102^{c}$ & 53 \\
\hline PCB $(0.3 \mathrm{~g} / \mathrm{kg})+\beta$-blocker & $14 \cdot 9^{\mathrm{a}}$ & 0.4 & $58 \cdot 3^{\mathrm{a}}$ & 1.9 & $70 \cdot 3^{c}$ & $1 \cdot 4$ & $2186^{\mathrm{c}}$ & 84 \\
\hline Tyrosine $(100 \mathrm{~g} / \mathrm{kg})$ & $15 \cdot 4^{\mathrm{a}}$ & 0.5 & $60 \cdot 3^{a}$ & 1.6 & $53 \cdot 8^{\mathrm{b}}$ & $1 \cdot 4$ & $1258^{\mathrm{b}}$ & 45 \\
\hline Tyrosine $(100 \mathrm{~g} / \mathrm{kg})+\beta$-blocker & $16 \cdot 5^{a}$ & 0.5 & $62 \cdot 5^{a}$ & 1.8 & $50 \cdot 4^{b}$ & $1 \cdot 0$ & $1308^{\mathrm{b}}$ & 68 \\
\hline
\end{tabular}

$a, b, c$ For each dietary supplement, mean values within the same vertical column with unlike superscript letters were significantly different: $P<0.05$.

excretion was significantly increased in rats fed on either the PCB or excess tyrosine diet. The feeding of PCB or excess tyrosine caused a significant increase in urinary excretion of norepinephrine, epinephrine and dopamine.

\section{Expt 2}

The effects of the chronic $\alpha$ - or $\beta$-blocker treatment on the hypercholesterolaemia induced by dietary excess tyrosine or PCB are shown in Tables 3-5. The pair-fed rats grew at a rate comparable to the $\alpha$-blocker-treated rats (Table 3 ). Hepatomegaly was observed in the $\alpha$ and $\beta$-blocker-treated rats given either the tyrosine $(100 \mathrm{~g} / \mathrm{kg})-$ or PCB $(0.3 \mathrm{~g} / \mathrm{kg})$ supplemented diet and their respective pair-fed groups. $\alpha$-Blocker-treated rats given either the tyrosine $(100 \mathrm{~g} / \mathrm{kg})$ - or PCB $(0.3 \mathrm{~g} / \mathrm{kg})$-supplemented diet had significantly lower serum cholesterol levels compared with the pair-fed groups given either the PCB or excess tyrosine diet without blocker treatment. Phenoxybenzamine-treated PCB-fed rats showed significantly higher serum cholesterol concentrations than pair-fed groups given the casein $(200 \mathrm{~g} / \mathrm{kg})$ basal diet. However, the hypercholesterolaemia induced by excess tyrosine or PCB diets was significantly lowered by the $\alpha$-blocker (phenoxybenzamine), whereas the administration of the $\beta$-blocker (propranolol) did not affect the serum cholesterol level.

Serum HDL-cholesterol and low-density lipoprotein (LDL)-cholesterol plus very-lowdensity lipoprotein (VLDL)-cholesterol values were significantly higher in the groups given either the PCB or excess tyrosine diet compared with the groups fed on the respective control diets. $\alpha$-Blocker-treated rats given either the tyrosine $(100 \mathrm{~g} / \mathrm{kg})$ - or PCB $(0 \cdot 3 \mathrm{~g} / \mathrm{kg})$ supplemented diet showed significantly lower serum HDL-cholesterol and LDL + VLDLcholesterol levels compared with the pair-fed groups given either the PCB or excess tyrosine diet alone.

\section{DISCUSSION}

Feeding PCB was found to be associated with an increase in serum total cholesterol, HDL-cholesterol, LDL + VLDL-cholesterol, urinary ascorbic acid and liver lipids accompanied by enlargement of the liver, which confirmed previous observations (Kato \& Yoshida, 1981). Hypercholesterolaemia induced by excess dietary tyrosine in the present 
study also confirmed previous observations (Nagaoka et al. 1985). Dietary tyrosine or PCB supplementation induced hypercholesterolaemia and increased both serum HDL-cholesterol and LDL + VLDL-cholesterol. Reiser et al. (1966) suggested that one function of serum HDL may be the transport of peripheral cholesterol to the liver. They have further indicated that the observed suppression in serum HDL of cholesterol-fed rats may be directly related to the decreased endogenous synthesis of cholesterol. It seems likely that cholesterol metabolism is quite different in rats given excess tyrosine or PCB from that in rats given cholesterol. Kato \& Yoshida (1980) found that hypercholesterolaemia induced by PCB stimulated the incorporation of ${ }^{3} \mathrm{H}_{2} \mathrm{O}$ into liver cholesterol and increased the activity of liver HMG-CoA reductase, suggesting stimulation of cholesterol synthesis. Furthermore, our preliminary observations (S. Nagaoka and A. Yoshida, unpublished results) suggested that feeding excess dietary tyrosine had the same effects. These findings suggested that the increase in serum cholesterol due to PCB or excess tyrosine intake could be mediated through the stimulation of hepatic cholesterol synthesis.

Urinary excretion of ascorbic acid was significantly increased in rats given either the PCB or excess tyrosine diet, but the increase was much greater in the PCB-fed group. Ascorbic acid is known to have a role in tyrosine metabolism. La Du \& Zannoni (1961) reported that ascorbic acid acted as a factor in maintaining normal tyrosine oxidation. Thus, excess dietary tyrosine might cause a significant increase in urinary excretion of ascorbic acid. On the other hand, previous observations suggested that the administration of xenobiotics such as PCB or DDT to rats increases the biosynthesis of ascorbic acid and accelerates concomitantly the turnover of ascorbic acid in the body (Horio \& Yoshida, 1982). There are several possibilities in relation to the effects of ascorbic acid on the hepatic drugmetabolizing system (Sato \& Zannoni, 1976). Moreover, Subramanian et al. (1974) and Nandi $e$ al. (1974) reported that a variety of stress conditions, namely administration of drugs and toxins, or dietary and physical stress, caused a rise in the tissue level of histamine. They suggested that administration of large doses of ascorbic acid in any of the stressful situations resulted in a marked decrease in the urinary histamine level, indicating detoxification of histamine in vivo. In the present study, urinary excretion of histamine was significantly increased in rats given either the excess tyrosine or PCB diet. The feeding of excess tyrosine or PCB per se may in fact cause stress to the animals, thereby stimulating the secretion of histamine.

Estimation of sympatho-adrenal medullary activity in animals is obtained by determination of catecholamine turnover in tissues, and concentrations in plasma and urine. Urinary catecholamine analysis seems to be more valuable than the plasma catecholamine analysis in some instances. By using urinary catecholamine analysis, Kvetnansky \& Mikulaj (1970) and Kvetnansky et al. (1978) showed that forced immobilization resulted in marked increases in urinary excretion of epinephrine and norepinephrine with concomitant elevation of their plasma levels. Thus, analysis of urinary catecholamines can be used for the evaluation of daily cumulative secretion of epinephrine and norepinephrine from the sympatho-adrenal medullary system.

Schwartz et al. (1983) indicated that high-fat diets produced an elevation in cardiac norepinephrine turnover with a concomitant increase in urinary norepinephrine. Estimation of sympatho-adrenal medullary activity in animals is often obtained by analysis of plasma catecholamine levels. However, Hansen et al. (1982) showed rapid fluctuations in plasma levels of catecholamines under undisturbed conditions. Because of the complexities in evaluating plasma catecholamine levels, urinary excretion of catecholamines has been used as a practical and valuable indicator (Euler, 1964; Kvetnansky \& Mikulaj, 1970). In the present study, urinary excretion of norepinephrine, epinephrine and dopamine was significantly increased in rats given the PCB or excess tyrosine diets. Thus, the feeding of 
excess tyrosine or PCB per se may cause stress to the animals, thereby stimulating the secretion of catecholamines.

The PCB and excess tyrosine diets caused a significant increase in the urinary output of dopamine (Table 2). This finding apparently resembles that of Kvetnansky et al. (1979) who showed that a variety of noxious stimuli cause a marked rise in serum concentration of dopamine in rats. The physiological meaning of the increase in urinary output of dopamine induced by dietary PCB or excess tyrosine remains obscure at present.

The regulation of cholesterol metabolism is subject to complex control and is altered by a number of environmental, hormonal and dietary factors. Insulin has an important role in controlling cholesterol synthesis (Nepokroeff et al. 1974). However, our preliminary observations indicated that the serum level of insulin was not significantly increased in rats given either PCB (Quazi, 1985) or excess tyrosine (S. Nagaoka and A. Yoshida, unpublished results). Furthermore, our preliminary observations indicated that dietary PCB caused a significant increase in the serum level of cholesterol in streptozotocin-induced diabetic rats as well as in normal animals (K. Kobayashi and A. Yoshida, unpublished results). The increase in serum cholesterol was greater in diabetic rats given PCB. Thus, these findings would suggest that the serum level of insulin does not have a major role in controlling the level of serum cholesterol in rats given either PCB or excess tyrosine.

Adrenergic receptors are ubiquitous and mediate several important factors involved in lipid metabolism. Epinephrine and norepinephrine have been shown to increase the rate of incorporation of $\left[1-{ }^{14} \mathrm{C}\right]$ acetate into non-saponifiable lipids and the activity of HMG-CoA reductase in rat hepatocytes (Edwards, 1975) or in vivo (Rajan \& Ramasarma, 1977). In fact, urinary excretion of catecholamines was stimulated together with an increase in the serum level of cholesterol by the excess tyrosine or PCB diets. Furthermore, the present study revealed that the administration of phenoxybenzamine, an $\alpha$-adrenergic blocker, caused a suppression of the increase in serum cholesterol level associated with the excess tyrosine or PCB diets. In addition, recent studies suggested that prazosin, an $\alpha$-blocker, reduces plasma cholesterol in rats (Dall'aglio et al. 1983). The present results agree with these findings. Hence, in the present work, we provide evidence that hypercholesterolaemia induced by PCB or excess tyrosine may result from a stress-induced adrenergic response. Further studies on this possibility are currently underway.

Hypercholesterolaemia induced by excess tyrosine or some xenobiotics would be a new model to elucidate not only the mechanisms of regulation of cholesterol metabolism, but also the regulation of lipoprotein metabolism.

The authors wish to thank Ajinomoto Co. Ltd, Japan, for the gift of tyrosine.

\section{REFERENCES}

Anton, A. H. \& Sayre, D. F. (1969). Journal of Pharmacological and Experimental Therapeutics 166, $285-292$.

Bartlett, G. R. (1959). Journal of Biological Chemistry 234, 466-468.

Dall'aglio, E., Chang, H. \& Reaven, G. M. (1983). Metabolism 32, 510-513.

Duncan, D. B. (1955). Biometrics 11, 1-42.

Edwards, P. A. (1975). Archives of Biochemistry and Biophysics 170, 188-203.

Euler, U. S. v. (1964). Clinical Pharmacology and Therapeutics 5, 398-404.

Folch, J., Lees, M. \& Sloane Stanley, G. H. (1957). Journal of Biological Chemistry 226, 497-509.

Gibbs, F. P. (1970). American Journal of Physiology 219, 288-292.

Hansen, B. C., Schielke, G. P., Jen, K.-L. C., Wolfe, R. A., Movahed, H. \& Pek, S. B. (1982). American Journal of Physiology 242, E40-46.

Harper, A. E. (1959). Journal of Nutrition 68, 405-418.

Harry, D. S., Dini, M. \& McIntyre, N. (1973). Biochimica et Biophysica Acta 296, 209-220.

Heimburger, M., Denoroy, L., Renaud, B., Sassard, J., Cohen, Y. \& Wepierre, J. (1983). Biochemical Pharmacology 32, 2739-2743. 
Horio, F. \& Yoshida, A. (1982). Journal of Nutrition 112, 416-425.

Ishikawa, T. T., McNeely, S., Steiner, P. M., Glueck, C. L., Mellies, M., Gartside, P. S. \& McMillin, C. (1978). Metabolism 27, 89-96.

Kato, N. \& Yoshida, A. (1980). Nutrition Reports International 21, 107-112.

Kato, N. \& Yoshida, A. (1981). Nutrition Reports International 23, 825-831.

Kissinger, P. T., Bruntlett, C. S., Davis, G. C., Felice, L. J., Riggin, R. M. \& Shoup, R. E. (1977). Clinical Chemistry 23, 1449-1455.

Kunihara, M. \& Oshima, T. (1983). Journal of Lipid Research 24, 639-644.

Kvetnansky, R. \& Mikulaj, L. (1970). Endocrinology 87, 738-743.

Kvetnansky, R., Sun, C. L., Lake, C. R., Thoa, N. B., Torda, T. \& Kopin, I. J. (1978). Endocrinology 103, 1869-1874.

Kvetnansky, R., Weise, V. K., Thoa, N. B. \& Kopin, I. J. (1979). Journal of Pharmacology and Experimental Therapeutics 209, 287-291.

La Du, B. N. \& Zannoni, V. G. (1961). Annals of the New York Academy of Sciences 92, 175 191.

Nagaoka, S., Aoyama, Y. \& Yoshida, A. (1985). Nutrition Reports International 31, 1137-1 148.

Nandi, B. K., Subramanian, N., Majumder, A. K. \& Chatterjee, I. B. (1974). Biochemical Pharmacology 23, 643-647.

Nepokroeff, C. M., Lakshmanan, M. R., Ness, G. C., Dugan, R. E. \& Porter, J. W. (1974). Archives of Biochemistry and Biophysics 160, 387-393.

Ohara, T. (1973). Shokuhinbunseki Handbook, pp. 301-305. Tokyo: Kenpaku Co.

Orr, M. L. \& Watt, B. K. (1957). Amino Acid Content of Foods. Washington DC: U.S. Dept. of Agriculture.

Pearson, S., Stern, S. \& McGavack, T. H. (1953). Analytical Biochemistry 25, 813-814.

Quazi, S. (1985). Effect of xenobiotics on cholesterol metabolism in rats. Ph.D. Thesis, Nagoya University, Nagoya, Japan.

Rajan, G. \& Ramasarma, T. (1977). Biochemical Journal 162, 493-499.

Reiser, R., Clark, D. A., Sorrels, M. F., Gibson, B. S., Williams, M. C. \& Wilson, F. H. (1966). Journal of Atherosclerosis Research 6, 565-579.

Sato, P. H. \& Zannoni, V. G. (1976). Journal of Pharmacology and Experimental Therapeutics 198, $295-307$.

Schwartz, J. H., Young, J. B. \& Landsberg, L. (1983). Journal of Clinical Investigation 72, 361-370.

Subramanian, N., Nandi, B. K., Majumder, A. K. \& Chatterjee, I. B. (1974). Biochemical Pharmacology 23, 637-641.

Wahlefeld, A. W. (1974). Methods of Enzymatic Analysis 4, 1831-1835.

Zilversmit, D. B. \& Davis, A. K. (1950). Journal of Laboratory and Clinical Medicine 35, 155-160. 